\title{
Research on the Development of Creative Industry in Shanghai: Based on the Perspective of 3T Theory
}

\author{
You Liu \\ School of Economics, Shanghai University, P.R. China \\ liuyouok@163.com
}

Keywords: Creative industry; Industrial development; 3T theory

\begin{abstract}
Creative industry which rises in the context of economic globalization is a cross-industry, strong penetration of knowledge-intensive emerging industry, it contains a huge economic and cultural value. Based on the 3T theory which was proposed by American sociologist Richard Florida, this paper studies the development of creative industries in Shanghai from the three perspectives of talent, technology and tolerance, and puts forward pertinent suggestions to promote the vigorous development of creative industries in Shanghai.
\end{abstract}

\section{Introduction}

The creative industry was developed in the context of global industrial restructuring and upgrading. It is one of the important indicators of measuring the industrial structure, economic vitality, urban function and consumption level of a country or region, and it is also one of the important force of the economic growth and competitiveness of modern cities. It is gradually becoming a major force in changing China's economic development patterns and urban economic transformation. As the pioneer of China's creative industry, Shanghai is at the front of China's Creative City Group. At the same time, the creative industries in the Pearl River Delta Creative Industry Cluster (Guangzhou, Shenzhen, etc.), the Central Creative Industries Cluster (Changsha, Wuhan), and the Sichuan-Shaanxi Creative Industry Cluster (Xi'an, Chongqing, and Chengdu) have a strong momentum of development. How Shanghai maintains its absolute superiority and continues to lead the list of China's creative cities deserves in-depth study. The article will use the perspective of 3T theory to analyze the development of Shanghai's creative industries and provide theoretical support and strategies for the future development of Shanghai's creative industries.

\section{Analysis of 3T theory index}

Talent index. The development of the creative industry relies on creative talents that combine wisdom, knowledge, and skills. Creative talents are the internal driving force and guarantee for the rapid development of China's creative industries. Talent indexes are mainly composed of two indicators: potential talents and existing talents. Specifically, they are measured by the number of college students attending, the number of postgraduate attending, the number of creative industry employees and the proportion of total employment.

Table 1 Analysis of talent indexes

\begin{tabular}{|c|l|}
\hline Index & \multicolumn{1}{|c|}{ Definition } \\
\hline Potential talent indexes & $\begin{array}{l}\text { The number of college students attending; The number of } \\
\text { postgraduate attending. }\end{array}$ \\
\hline Existing talent indexes & $\begin{array}{l}\text { The number of employees in the creative industry; The percentage } \\
\text { of employees in creative industries in total employment }\end{array}$ \\
\hline
\end{tabular}

Technology index. In the creative industry, technology refers to a city's innovative and high-tech concentrated expression. Areas where the creative industries are prosperous are often areas where technological innovation is frequent. The technical indexes can be composed of two major 
indicators: R\&D and technological invention patents. Specifically, they are measured in terms of internal expenditure of R\&D funds as a percentage of GDP and the number of patents authorization.

Table 2 Analysis of Technology indexes

\begin{tabular}{|c|l|}
\hline Index & \multicolumn{1}{c|}{ Definition } \\
\hline R\&D & Internal expenditure of R\&D funds as a percentage of GDP \\
\hline Technological invention patents & The number of patent authorization \\
\hline
\end{tabular}

Tolerance index. Tolerance can be defined as open, inclusive and diverse. Tolerance plays a key role in attracting creative talents and supporting the development of high-tech industries and urban economic growth. The cultural environment of the city and the openness of the city reflect, to some extent, the development of a city's inclusive environment. A good cultural environment and an open urban environment can stimulate the birth of new ideas and thus social creativity. The tolerant indexes can be composed of two indicators: cultural environment and openness of the city. Specifically, it is measured in terms of the added value of the Shanghai's cultural industry, and the proportion of the overseas and permanent residents.

Table 3 Analysis of Tolerance indexes

\begin{tabular}{|c|c|}
\hline Index & Definition \\
\hline Cultural environment & The added value of Shanghai's cultural industry \\
\hline Openness of city & The proportion of the overseas and permanent residents \\
\hline
\end{tabular}

\section{An Analysis of the Development of Shanghai's Creative Industry from the Perspective of 3T Theory}

Analysis of talent indexes. (1) The number of college students attending and the number of postgraduate attending. The cultural and creative industries need more talent than any other industry. They rely less on resources and funds than any industry. They rely more on talent and potential creative industry talents are the driving force behind the development of the industry. It can be seen from Table 4 that in 2015, the number of university students attending colleges in Shanghai was as high as 510,000, and the number of graduate students attending was approximately 140,000 , and the trend of year-on-year growth was generally maintained. Sufficient to see the development of creative industries in Shanghai has more adequate personnel protection.

At the same time, after a regression analysis of the number of students attending Shanghai universities (including undergraduates and postgraduate students) and Shanghai's GDP for 15 consecutive years from 2001 to 2015, the following three functional relationships exist between the two:

$$
\mathrm{y}=2 e^{-12} x^{3}-2 e^{-6} x^{2}+0.956 x-131923
$$

The correlation coefficient $R^{2}$ of the two is 0.9711 , showing a highly significant correlation. It shows that the increase in the number of students in colleges and graduates is playing an important role in driving GDP growth. 
Table 4 The number of college students, postgraduate attending, and GDP values in Shanghai

\begin{tabular}{|c|c|c|c|c|c|c|}
\hline Years & $\begin{array}{c}\text { The number of } \\
\text { college students } \\
\text { attending }\end{array}$ & $\begin{array}{c}\text { growth } \\
\text { rate } \\
{[\%]}\end{array}$ & $\begin{array}{c}\text { The number of } \\
\text { postgraduate } \\
\text { attending }\end{array}$ & $\begin{array}{c}\text { growth } \\
\text { rate [\%] }\end{array}$ & $\begin{array}{c}\text { GDP [Ten Billion } \\
\text { RMB] }\end{array}$ & $\begin{array}{c}\text { growth } \\
\text { rate [\%] }\end{array}$ \\
\hline 2001 & 283908 & 25.18 & 39043 & 27.53 & 5210.12 & 10.5 \\
\hline 2002 & 331630 & 16.81 & 48896 & 25.24 & 5741.03 & 11.3 \\
\hline 2003 & 378517 & 14.14 & 59090 & 20.85 & 6694.23 & 12.3 \\
\hline 2004 & 415701 & 9.82 & 69437 & 17.51 & 8072.83 & 14.2 \\
\hline 2005 & 442620 & 6.48 & 78728 & 13.38 & 9247.66 & 11.4 \\
\hline 2006 & 466333 & 5.36 & 86906 & 10.39 & 10572.24 & 12.7 \\
\hline 2007 & 484873 & 3.98 & 91763 & 5.59 & 12494.01 & 15.2 \\
\hline 2008 & 502899 & 3.72 & 95498 & 4.07 & 14069.87 & 9.7 \\
\hline 2009 & 512778 & 1.96 & 103492 & 8.37 & 15046.45 & 8.2 \\
\hline 2010 & 515661 & 0.56 & 111717 & 7.95 & 17165.98 & 10.3 \\
\hline 2011 & 511283 & -0.85 & 119017 & 6.53 & 19195.69 & 8.2 \\
\hline 2012 & 506596 & -0.92 & 127014 & 6.72 & 20181.72 & 7.5 \\
\hline 2013 & 504771 & -0.36 & 134799 & 6.13 & 21818.15 & 7.7 \\
\hline 2014 & 506644 & 0.37 & 133554 & -0.92 & 23567.7 & 7 \\
\hline 2015 & 511623 & 0.98 & 138287 & 3.54 & 25123.45 & 6.9 \\
\hline
\end{tabular}

Source: Shanghai Statistical Yearbook (2000-2016)

(2) Percentage of Shanghai's creative industry employees in total employees. In 2003, there were only 167,500 employees in creative industries in Shanghai. By 2013, this figure has increased by nearly 8 times to 1.3 million. In 2010, Shanghai's creative industry practitioners accounted for over $10 \%$ of the total ratio of employees, and have remained above $10 \%$ since then, but compared with traditional industries (such as transportation, warehousing and postal services, accounting for about 50\%). There is still a big gap.
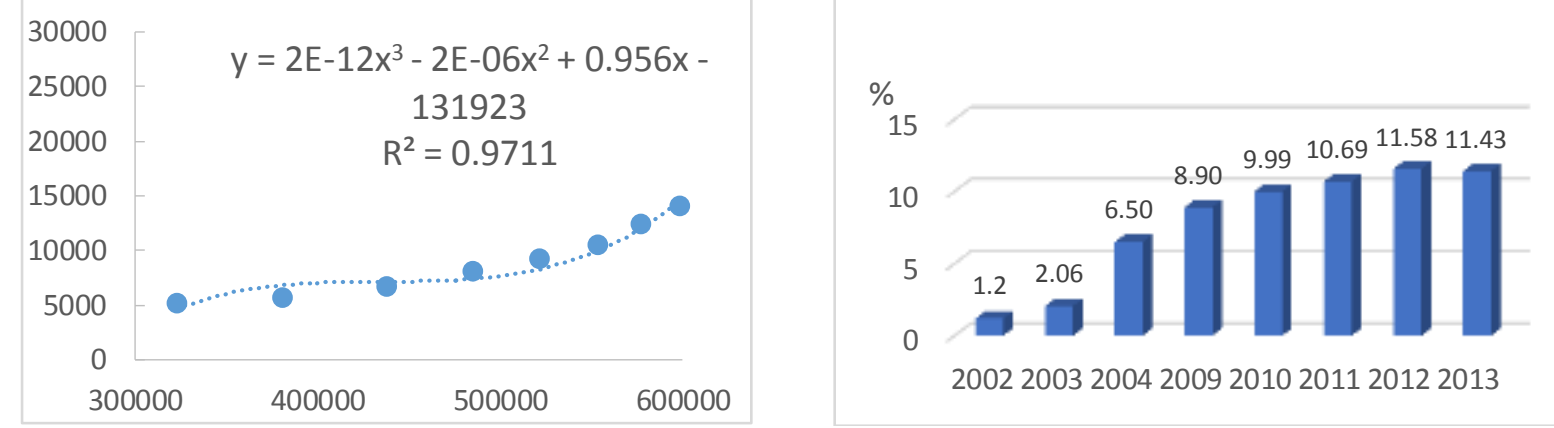

Figure 1. Scatter diagram of the number of college students and Shanghai's GDP (left)

Figure 2. Ratio of Creative Industry employees to Total employees in Shanghai (Right)

Analysis of technology indexes. (1) Internal expenditure of R\&D funds as a percentage of GDP. Technology can leverage the development of the creative industry and can bring leapfrog development to the industry. The regression analysis of Internal expenditure of R\&D funds and GDP data in Shanghai for consecutive 16 years shows that there is a cubic function relationship between the two: $y=0.000015 x^{3}-0.034965 x^{2}+44.963462 x+1419.42$. The correlation coefficient between the two is about 0.9986 , showing a highly significant correlation, indicating that investment in $R \& D$ expenditures will affect the development of the industry and thus affect economic development.

However, the investment intensity of $R \& D$ expenditure in Shanghai is very low. In 2015, it accounted for only $3.73 \%$ of the total value of GDP, which is far from sufficient compared with 
some developed countries. In the future development of the creative industries, the Shanghai government should consider the investment in $\mathrm{R} \& \mathrm{D}$ funding as an entry point and continue to increase investment in $R \& D$ funding.

(2) The number of patent authorization. The number of patent grants refers to the number of patents granted by the patent administrative department during the reporting period, which is the sum of the number of patents granted for inventions, practical novelties, and designs. Observing Fig. 4, we can see that, overall, the number of patent grants in Shanghai shows an increasing trend, with the largest increase in 2010, which is 7 times that of 2002. In 2015, it has exceeded the 60,000 mark.



Figure 3. Scatter diagram of internal expenditure of R\&D funds and Shanghai's GDP (left)

Figure 4. The number of patent authorization (Right)

Analysis of tolerance indexes. (1) The added value of Shanghai's cultural industry. Cultural activities are closely related to innovation and creativity. Regions with deep cultural heritage often have greater potential for innovation and creativity. In 2015, Shanghai's cultural industry realized an added value of 163.268 billion yuan, an increase of $8.1 \%$ over the same period of last year, an increase of $1.2 \%$ over the same period of regional GDP.

In December 2016, Shanghai's "Thirteenth Five-Year Plan" was issued, proposing that in the next five years, Shanghai will work hard to build a national cultural center. By the year 2020, an international cultural metropolis will be basically established with a combination of cultural elements, good cultural ecology, prosperous cultural undertakings, developed cultural industries, active cultural innovations, cultural talents, frequent cultural exchanges, and colorful cultural life. Under this strategic background, the future of Shanghai's creative industries is promising.

(2) The proportion of the overseas and permanent residents. In 2015, the number of foreign permanent residents in Shanghai reached 178,000. Although the number is large, the proportion is only $0.74 \%$. Of course, this ratio is merely an index measuring Shanghai's opening. It does not mean that Shanghai's degree of openness to the outside world is too low. From the combination of other indicators such as the number of international tourist arrivals ( 8 million in 2015), it can be seen that Shanghai is undoubtedly a highly open and diversified city.

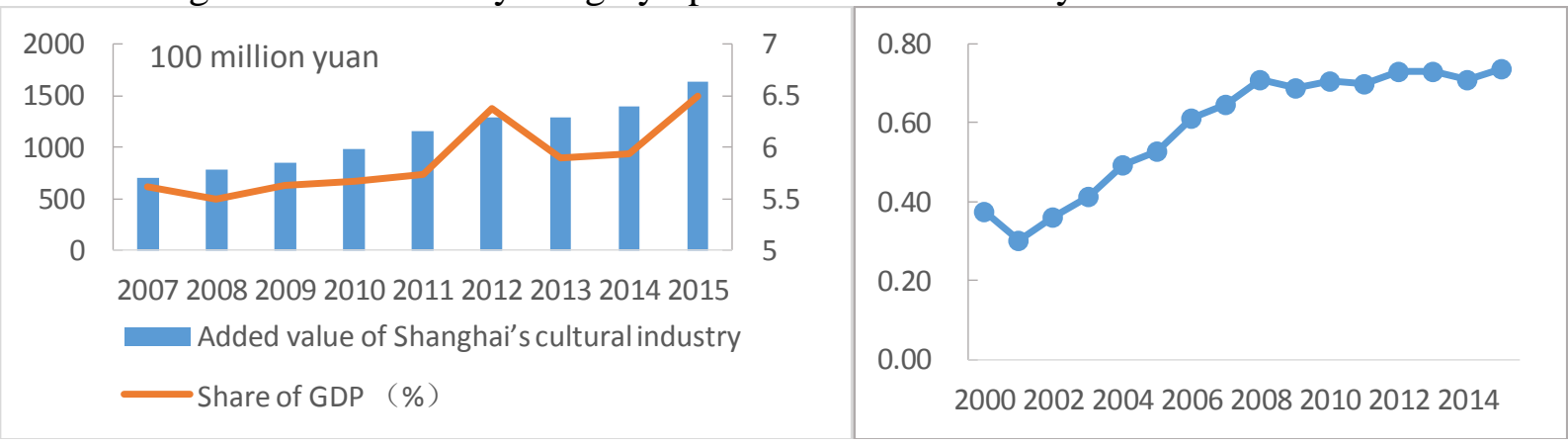

Figure 5. The added value of Shanghai's cultural industry and its share of GDP (left)

Figure 6. Population ratio of Shanghai's overseas and permanent population (Right) 


\section{Strategy suggestion.}

Emphasis on the cultivation of creative talents and the combination of production, education and research. Although the number of undergraduates and postgraduates in Shanghai colleges and universities is relatively large, the cultivation of creative talents in colleges and universities is still far from enough, and the employment intention of college graduates in creative industries is not strong. Therefore, when developing creative industries, Shanghai should rationally use high-efficiency resources, cooperate with creative enterprises, establish practical teaching bases, integrate production, education and research, and pay attention to cultivating effective students' innovative and social skills.

Relying on high-tech development to promote the optimization and upgrading of creative industries. As a knowledge-intensive and technology-intensive industry, the creative industry needs science and technology as its core driving force for development. Therefore, it is necessary to increase capital investment in the scientific research of creative companies, enhance the ability of independent innovation in $\mathrm{R} \& \mathrm{D}$, and cultivate a group of creative industry groups with independent intellectual property rights and core technologies. Through the clustering and diffusion effects of industrial clusters, the innovation capabilities of the enterprises within the cluster are enhanced.

To maintain an inclusive and open environment, the government plays a leading role. In order to create an inclusive and open policy environment, the Shanghai government should provide accurate industry positioning for the characteristics and development trends of creative industries, determine the industry scope, formulate development plans, and establish and improve the policy system of creative industries including industrial structure policies, industrial technology policies, industrial organization policies, and industrial market policies.

\section{References}

[1] Hutton, Thomas A...Spatiality, built form, and creative industry development in the inner city. Environment \& Planning[J],2006,38(10):1819-1841.

[2] W.W Li, H.M Wang, Creative Industry Promoting the Changing of the Ways of Economic Growth. China Industrial Economy[J],2006-11.

[3] M. Chen, A Study on the Path Options for Urban Creative Industry Based on 3T Theory. On Economic Problems[J],2010-04.

[4] H.C Wang, X.D. Qiao, The Development Strategies for Hangzhou Creative Clusters:A Research in Perspective of 3T Theory. Reformation \& Strategy[J],2009-02. 